\title{
ANALISIS KEMAMPUAN PENGGUNAAN KATA KERJA PADA ANAK USIA 5 TAHUN
}

\author{
Oleh: \\ Yubaedi Siron, \\ Universitas Negeri Jakarta \\ sironyubaedi9 $\overline{1}$ gmail.com
}

\begin{abstract}
Abstrak
Penelitian ini bertujuan untuk mengetahui kemampuan anak usia 5 tahun dalam menggunakan kata kerja. Penelitian ini menggunakan pendekatan kualitatif. Subjek penelitian ini anak usia 5 tahun yang ada di kompleks jalan pemuda II kelurahan Rawamangun Jakarta Timur. Data dianalisis dengan mereduksi data, display data dan verifikasi data. Teknik pengumpulan data dilakukan dengan observasi, wawancara dan dokumentasi. Penelitian ini mengungkapkan bahwa kata yang dihasilkan oleh anak usia dini sangat banyak. Kata kerja yang diucapkan sudah dapat diketahui dan dipahami oleh teman bermainnya. Data yang muncul, pada tahap ini anak dalam menggunakan kata kerja masih menggunakan kata dasar. Pengucapan anak dalam menggunakan kalimat beberapa masih belum jelas. Penelitian ini mengungkapkan bahwa penggunaan kata kerja pada anak usia 5 tahun tidak diimbangi dengan penggunaan kalimat yang lengkap/kompleks. Penelitian ini juga mengungkapkan bahwa anak usia 5 tahun sudah mulai dapat bercanda dengan kata-kata.
\end{abstract}

Kata Kunci: kemampuan, kata kerja, anak usia lima tahun.

\section{Abstract}

The objectives of the research is to determine the ability of 5 years old chidren in the use of the verb. This study used a qualitative approach. The subjects were5 years old children in Pemuda II Rawamangun, East Jakarta. Datawas analyzed data reduction, data display and data verification. Data was collectedbyobservation, interviewanddocumentation. This studyrevealsthat thewordproducedby younger childrenverymuch. The verbispronouncedalreadybe knownandunderstood byhis playmates. The dataappear, at this stagethe childin using theverbstillusingbasic words. Pronunciationchildin usingthe phrasestill unclear. This studyrevealedthat theuse ofverbsin children5 years old are notoffset bythe use ofa completesentence/complex. The study alsorevealedthat 5 year-old-children have startedtojokewith words.

Keywords: ability, verb, five-year-old children.

\section{PENDAHULUAN}

Sisdiknas Tahun 2003 Pasal 1

Ayat 14 menyatakan bahwa pendidikan anak usia dini adalah suatu upaya pembinaan yang ditujukan kepada anak sejak lahir sampai dengan usia enam tahun yang dila-kukan melalui pemberian rangsangan pendidikan untuk mengacu pertumbuhan dan perkembangan jasmani dan rohani agar anak memiliki kesiapan dalam memasuki pendidikan lanjutan.
Perkembangan bahasa untuk anak taman kanak-kanak berdasarkan acuan standar pendidikan anak usia dini No. 58 tahun 2009, mengem-bangkan tiga aspek yaitu menerima bahasa, mengungkapkan bahasa, dan keaksaraan.

Bloom dalam Musbikhin (2010) mereview beberapa studi dan menyimpulkan bahwa antara umur 2 sampai $\quad 10$ tahun, anak-anak mengembangkan kemampuan kognitif 
seperti bahasa dan keterampilan seperti orang dewasa.

Perkembangan bahasa pada anak usia dini sangat mempengaruhi perkembangan kognitif pula. Karena kognitif memiliki keterkaitan dengan bahasa, sehingga dalam pendidikan anak usia dini bahasa dan kognitif sangat penting untuk diberikan berbagai macam stimulasi agar ber-kembang sesuai dengan tugas-tugas perkembangan.

Yamin dan Sabri (2010) menyatakan pada aspek pengembangan bahasa, kompetensi dan hasil yang diharapkan adalah anak mampu menggunakan bahasa sebagai pema-haman bahasa pasif dan dapat berkomunikasi secara efektif yang bermanfaat untuk berfikir dan belajar dengan baik.Anak mampu meng-gunakan bahasa dengan baik di-pengaruhi oleh beberapa faktor, salah satunya adalah faktor kematangan usia.

Permasalahan di lapangan menggambarkan bahwa perkembangan bahasa anak usia dini sangat kompleks. Beberapa anak usia dini belum bisa mengekspresikan dan komunikasikan serta memberitahukan sesuatu kepada orang lain. Hal ini akan menjadikan permasalahan yang serius jika tidak diteliti dan diberi solusi. Padahal syarat utama terjadinya komunikasi yang baik yaitu bahasa yang jelas dan dapat dipahami serta sesuai kaidah berbahasa dari pihak yang memberi pesan (komunikator) yang dalam hal ini yaitu anak usia dini khususnya yang berusia 5 tahun, karena mereka sudah bersosialisasi dan butuh untuk mengembangkan perannya dalam berkomunikasi bersama orang-orang di lingkungan sekitarnya. Penggu-naan kata kerja dalam percakapan sehari-hari anak masih belum ideal. Anak-anak masih belum tepat dalam penggunaan kata. Lebih dari itu, anak-anak sebagian masih menggunakan kata yang berbeda konteks dan tidak menuju pada tujuan dan maksud dari sesuatu yang ingin dikomunikasikannya. Untuk itu menganalisis penggunaan kata kerja oleh anak usia 5 tahun merupakan hal yang sangat penting. Komponen kemampuan penggunaan kata kerja menjadi penting dari merupakan salah satu komponen berbahasa manusia.

Jalongo (2007) menyatakan belajar bahasa merupakan sebuah tantangan karena tidak hanya yang anak-anak duga bagaimana belajar tentang bahasa tapi bagaimana mereka belajar melalui bahasa. Anak usia dini merupakan masa periode tercepat dalam pengembangan bahasa. Anak akan menanggung konsekuensi yang panjang jika anak gagal untuk mendapat dukungan sebagai pembelajar bahasa pada waktu yang kritis ini. Kepercayaan diri anak dan keterampilan sebagai pembelajar bahasa dan penggunaan bahasa akan menjadi bahaya bagi anak jika tidak mendapat kesempatan pendidikan kebahasaan dengan baik. Imbas dari masalah ini berdampak pada perilaku anak, sebagai contoh anak yang tidak dapat menggunakan kata dengan baik dalam mengutarakan ketidaksetujuan akan menjadi anak berperilaku agresif, anak yang tidak suka bahasa akan memilih menjadi anak yang diam, bahkan berlanjut pada anak yang berjuang untuk berlatih membaca permulaan, anak akan menyerah untuk melanjutkan sekolah. Berdasarkan permasalahan tersebut, peneliti mengambil judul penelitian "Analisis kemampuan penggunaan kata kerja pada anak usia 5 tahun di kompleks Jalan Pemuda II Rawamangun Jakarta Timur."

Tujuan penelitian ini yaitu untuk mengetahui kemampuan anak usia 5 tahun dalam menggunakan kata kerja, dan bagaimana deskripsi anak usia 5 tahun dalam mengguna-kan kata kerja dalam percakapan se-hari-harinya sehingga dapat menganalisis penggunaan kata kerja anak usia 5 tahun yang akan berkontribusi positif dalam mengembangkan bahasa anak usia dini.

\section{METODE}

Penelitian inimenggunakanmetode kualitatif. Data diambil dengan melakukan 
observasi, wawancara, dan dokumentasipada anak usia 5 tahun. Penelitianini dilaksanakan di kompleks Pemuda II Kelurahan Rawamangun Kecamatan Pulo Gadung Jakarta Timur. Penelitian ini dilaksanakan bulan OktoberDesember 2013. Fokus penelitian adalah kemampuan penggunaan kata kerja pada anak usia 5 tahun dengan latar dalam penelitian ini adalah anak usia 5 tahun yang ada di kompleks Pemuda II. Sumber data dalam penelitian ini adalah anak usia Tabel 1. Hasil Data Penelitian

\begin{tabular}{|c|c|c|}
\hline No & $\begin{array}{l}\text { Kalimat yang diucapkan } \\
\text { anak }\end{array}$ & Konteks percakapan anak \\
\hline 1 & Bisa & $\begin{array}{l}\text { Radit menjawab pertanyaan peneliti berikut, "bisa nggak adiknya main hollahop?, } \\
\text { coba..." }\end{array}$ \\
\hline 2 & Saya bisa om & Asha (teman Radit) menyeletuk, bahwa dirinya juga bisa memainkan holahop \\
\hline 3 & Udah & Radit menjawab pertanyaan peneliti berikut: "Adik udah sekolah apa belum? \\
\hline 4 & Nyanyi... & Anak-anak menjawab pertanyaan peneliti "Diajar apa saja disekolah?" \\
\hline 5 & Buguru nyanyi.. & $\begin{array}{l}\text { Anak-anak memberitahukan bahwa di sekolah mereka diajari menyanyi oleh } \\
\text { gurunya. }\end{array}$ \\
\hline 6 & $\begin{array}{l}\text { Radit gue besok main } \\
\text { sepeda ya... }\end{array}$ & Asha memohon Radit besok bermain sepeda bersama. \\
\hline 7 & Main sepeda ama holahop & $\begin{array}{l}\text { Anak-anak memberitahu peneliti bahwa mereka selain bermain sepeda juga } \\
\text { bermain holahop }\end{array}$ \\
\hline 8 & Udah bisa ngegenjot.. & $\begin{array}{l}\text { Radit menjawab rasa tidak percaya peneliti bahwa dirinya sudah dapat mengayuh } \\
\text { sepeda. }\end{array}$ \\
\hline 9 & Saya juga bisa & $\begin{array}{l}\text { Asha menambahi lagi bahwa dirinya juga dapat mengayuh lagi seperti yang } \\
\text { dilakukan Radit. }\end{array}$ \\
\hline 10 & Gak bisa.. & $\begin{array}{l}\text { Anak-anak mengabarkan bahwa mereka tidak dapat masuk ke holahop secara } \\
\text { bersama-sama. }\end{array}$ \\
\hline 11 & Saya udah sholat & Radit memberitahu peneliti bahwa dia sudah sholat. \\
\hline
\end{tabular}

Penelitian ini mengungkapkan bahwa kata yang dihasilkan oleh anak usia dini sangat banyak. Sebelum terklasifikasi dan direduksi dalam kategori kata kerja diatas, puluhan kalimat telah terproduksi oleh anak dalam waktu beberapa menit. Hal ini didukung oleh pendapat Beaty (2013) yang menyatakan bahwa anak usia 5 tahun berada pada tahap produksi awal dan menuju ke tahap perluasan produksi, yang artinya bahwa nak-anak merespon pertanyaan dan kegiatan dalam frasa singkat. Mereka terlibat dalam percakapan sederhana, lebih lanjut pada tahap perluasan produksi, anak-anak bicara dalam kalimat panjang, mengajukan pertanyaan, mengisahkan cerita, melakukan permainan peran, dan melakukan percakapan panjang.
5 tahun yang ada di kompleks Pemuda II Rawamangun Jakarta Timur. Analisis data yang dipakai adalah model Miles and Huberman yang meliputi data reduction (reduksi data), penyajian data, dan menarik kesimpulan/verifikasi.

\section{HASIL DAN PEMBAHASAN}

Analisis hasil penelitian yang telah dilakukan, terdaftar kalimat berikut yang termasuk dalam kategori kata kerja yang diucapkan oleh anak usia 5 tahun.

\section{Konteks percakapan anak}


perkembangan bahasa, anak paling tidak dapat berkomunikasi dengan orang dewasa dan anak-anak lain, bisa menyampaikan apa yang diinginkan dan bisa dimengerti orang lain, mampu memahami apa yang disampaikan orang lain.

$$
\text { Pengucapan anak dalam }
$$

menggunakan kalimat berita beberapa masih belum jelas. Ada beberapa kata yang kurang jelas dalam pengucapannya seperti "Bu guru nyanyi". Anak-anak kurang jelas dalam melafalkannya, sehingga menjadikan peneliti berulangulang menanyakan kepada anak apa yang dimaksudkan oleh anak. Anak masih egosentris tanpa melihat lawan bicaranya. Senada dengan Catron dan Allen (1999) yang menjelaskan bahwa para peneliti telah mempelajari egosentrisme anak-anak dalam komunikasi dengan orang lain. Sebagian besar penelitian tersebut telah difokuskan pada tugas-tugas komunikasi referensial, yaitu meminta bahwa anak berkomunikasi dengan orang lain tentang objek tertentu atau peristiwa tentang yang pendengar memiliki perspektif yang berbeda atau jumlah informasi dari anak. Sebuah studi, peneliti meminta anak-anak berusia 4 tahun untuk menunjukkan mainan baru untuk anak muda dan orang dewasa. Peneliti juga menemukan bahwa anak-anak akan beradaptasi komunikasi mereka agar lebih mudah dipahami oleh anak-anak dengan keterbelakangan mental. (Guralnick dan Paul-Brown dalam Catron dan Allen:1999).

Penelitian tersebut muncul untuk membantah klaim Piaget dan Inhelder dalam Catron dan Allen (1999) bahwa anak-anak prasekolah yang egosentris, atau tidak mampu untuk mempertimbangkan perspespi orang lain, dalam komunikasi mereka. Sebenarnya masalah ini jauh lebih kompleks dari yang terlihat. Sebuah studi dari anak 4 sampai 6 tahun, kemampuan untuk menafsirkan efek dari ambigu dan pesan informatif pada kemampuan pendengar untuk menemukan objek tersembunyi, pada usia 6 tahun lebih efektif membedakan dua jenis pesan dan apakah pendengar akan mampu menemukan objek tersembunyi dengan informasi yang diberikan dalam setiap pesan. Usia empat tahun lebih sering menjawab berdasarkan pengetahuan mereka sendiri dari objek tersembunyi dari pada pengetahuan pendengar (Sodian dalam Catron dan Allen:1999) penelitian tersebut menunjukkan bahwa anak diberi tugas komunikasi yang sangat kompleks, dalam hal ini harus mengevaluasi baik pesan dan efeknya pada pendengar, sulit bagi anak-anak. Menghadapi tantangan tersebut, mereka bergantung pada metode lebih egosentris dalam merespons, namun dalam komunikasi referensial sederhana, anak-anak bisa beradaptasi dan melakukan komunikasi mereka dengan kebutuhan informasi dan kemampuan pemahaman pendengar mereka.

Sisi lain dari kesadaran fonologi pada anak, pengucapan yang yang kurang baik pada anak biasanya kurang menguntungkan anak. Imbas dari kurang baiknya pengucapan akan berdampak pada perkembangan berikutnya. Anak-anak mungkin akan belajar tentang huruf, tapi mereka tidak dapat membaca dan melafalkan kata yang tidak familiar. Fakta yang kuat mengindikasikan bahwa anak yang berada pada level bawah di kelasnya dengan kesadaran fonologi akan berlanjut pada kemampuan membacanya yang rendah ketika berada di SD kelas awal. (Kostelnik, Soderman, dan Whiren, 2007).

Penelitian ini mengungkapkan bahwa penggunaan kata kerja pada anak usia 5 tahun tidak diimbangi dengan penggunaan kalimat yang lengkap/ kompleks. Anak-anak masih menggunakan komponen pembentuk kalimat yang kurang sesuai seperti "Bisa", "Saya bisa om", "Udah", "Nyanyi", "Udah bisa ngegenjot", dan "Gak bisa".

Temuan ini berlainan dengan pendapat Beaty (2013) yang menyatakan bahwa anak kecil berusia 3, 4, dan 5 tahun paling cepat perkembangan bicaranya, dari frasa sederhana yang mereka ucapkan sebelumnya mereka tiba-tiba bisa 
memperluas subjek dan predikat kalimat mereka menjadi pemikiran yang lebih panjang dan kompleks. Temuan dalam penelitian ini masih ada beberapa kalimat yang diucapkan anak-anak bahkan masih belum terlihat komponen-komponen pembentuk kalimat yang lengkap seperti subjek, predikat, dan objek. Kasus dalam temuan penelitian ini menandakan bahwa temuan Beaty (2013) tidak dapat digeneralisasikan oleh semua anak di dunia ini dengan umur yang sama. Hasil penelitian ini juga menandakan bahwa anak mempunyai karakter dan perkembangan masing-masing yang berbeda satu sama lain. Temuan ini didukung oleh pendapat Sujiono (2010) yang menyatakan bahwa setiap anak berkembang melalui tahapan perkembangan yang umum tetapi pada saat yang sama setiap anak juga adalah makhluk individu yang unik. Anak usia dini aktif secara terus-menerus medapat informasi mengenai dunia lewat permainannya; setiap anak mengalami kemajuan melalui tahapan-tahapan perkembangan yang dapat diperkirakan; anak bergantung dalam hal pertumbuhan kognitif (bahasa) dan kognitif dalam interaksi sosial; anak merupakan individu yang unik yang tumbuh dan berkembang dengan kecepatan yang berbeda.

Piaget dalam Catron dan Allen (1999) di sisi lain menggambarkanbahasa sebagai hasil dari perkembangan kognitif individu dan internal anak. Bahasa orang dewasa mempengaruhi bahasa anak, tetapi tidak di luar batas kemampuan kognitif anak itu sendiri. Anak mengeksplorasi, menemukan, dan memanipulasi bahasa karena mereka terlibat dalam permainan kata, dengan cara sadar bahwa mereka mencari, menemukan dan memanipulasi lingkungan fisik mereka untuk belajar tentang dunia mereka dengan tindakan mereka pada saat mereka dunia mereka. Bagaimanapun menggambarkan pemelajaran bahasa sebagai proses sosial. Anak-anak belajar bahasa saat mereka berinteraksi dengan orang dewasa dan teman sebaya. Piaget melihat bahasa sebagai pengembangan dari individu ke sosial. Vygotsky melihat bahasa sebagai pengembangan dari sosial untuk faktor penunjang kognitif internal dan kemampuan memecahkan masalah.

Catron dan Allen (1999) menyatakan penelitian di bidang pendidikan anak usia dini telah mengungkapkan faktor kurikuler dan program yang berhubungan dengan perkembangan bahasa anak-anak. Anakanak yang didorong untuk terlibat dalam permainan sosiodrama terstruktur dan diberikan materi yang tepat untuk digunakan dalam bermain seperti memiliki keterampilan komunikasi yang lebih efektif saat bermain. Sebagai contoh, dalam sebuah studi dari anak usia 4 dan 5 tahun, anak-anak menghasilkan bahasa yang lebih rinci di sentra bermain drama, seperti kantor dokter, seperti permain kruksi dengan menggunakan blok-blok. Anak-anak berpura-pura menjadi dokter, dan lebih suka mengungkapkan keinginan mereka.

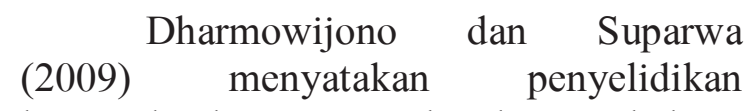
longitudinal tentang perkembangan bahasa pada anak-anak berusia 5 tahun keatas menunjukkan bahwa pertumbuhan yang menyolok dengan kemampuan berkomunikasi secara efektif. Perkembangan yang terlihat yaitu bahasa yang dipakai semakin lancar; salah bicara semakin dihindari; kesalahan dalam struktur semakin berkurang; panjang kalimat semakin bertambah; kalimatkalimat pendek dirangkaikan dengan kata penghubung "lalu", "terus"; transformasi yang digunakan semakin banyak, sehingga kalimatnya semakin rumit. Penyelidikan longitudinal tersebut tidak sepenuhnya benar, hal tersebut di buktikan dalam kasus yang ditemukan di penelitian ini, karena melihat perkembangan setiap anak yang berbeda, menjadikan perkembangan setiap anak itu memiliki keunikan dan perbedaan karakteristik dalam perkembangannya. Goldscheneider dan DeKeyser dalam Brown (2007) menyatakan ada 
beberapa faktor yang menentukan tentang urutan pemerolehan bahasa anak yaitu menonjolnya per-septual (seberapa mudah melihat atau mendengar struktur tertentu); kompleksitas semantik (seberapa banyak makna yang diungkapkan oleh suatu bentuk tertentu); keteraturan morfologis (sampai ditingkat mana bentuk-bentuk bahasa dipengaruhi oleh lingkungan fonologis mereka); kategori sintaksis (karakteristik gramatikal pada bentukbentuk); dan frekuensi dalam masukan (berapa kali sebuah struktur muncul dalam tuturan seorang anak).

$$
\text { Kalmar dalam Beaty (2013) }
$$

menambahkan lingkungan yang kaya ujaran, sebuah tempat yang menerima dimana orang dewasa/ guru mendorong anak kecil bicara, dan mereka mencontohkan penggunaan penekanan, pengaturan, dan dialek membantu anakanak mengembangkan dan mengasah kemampuan bahasa mereka.

Penelitian tentang pengaruh lingkungan terhadap perkembangan bahasa anak-anak telah menemukan bahwa sebagian besar kosakata awal anak terdiri dari kata-kata yang mewakili benda-benda dan perilaku di lingkungan terdekat anak seperti orang-orang yang akrab atau benda, tindakan (memberi), atau penghargaan dan hukuman (baik, buruk) (Nel-son, dalam Catron dan Allen:1999). Orang dewasa di lingkungan juga mempengaruhi pembelajaran bahasa anak, ketika orangtua menggunakan bahasa sederhana, seperti banyak kata benda dan struktur tata bahasa sederhana, bukan bahasa yang lebih kompleks, seperti banyak kata kerja dan kata ganti dan bahasa yang lebih abstrak, anak-anak memiliki kemampuan bahasa yang lebih baik.

Gestwicki (2006) menyatakan komponen literasi yang umumnya diakui sebagai dasar komponen penting yaitu: pemerolehan kosa kata dan bahasa, pemerolehan kesadaran fonologi, mempunyai alur pengetahuan, mempunyai pengetahuan huruf dan kata, dan melihat literasi sebagai sumber kesenangan.
Lingkungan pendukung untuk anak usia 5 tahun dalam perkembangan bahasa dimulai dari kemampuannya mengerti tentang literasi awal dan komponen keterampilannya, yang menekankan pada semua bentuk komunikasi anak untuk mewakili konsep dan pengalamannya kepada yang lain. Anak-anak mendorong untuk mengembangkan bahasa oral dan keterampilan mendengarkan melalui percakapan dengan teman bermainnya dan orang-orang dewasa.

Permasalahan anak dalam pemerolehan bahasa yaitu dipengaruhi oleh faktor kompetensi dan performa anak, pemahaman dan produksi, bakat alam dan pengaruh lingkungan, karakteristik universal, sistematisitas dan variabilitas, bahasa dan pemikiran, peniruan, latihan dan frekuensi, masukan, dan wacana. (Brown, 2007).

Pemerolehan bahasa tersebut erat kaitannya dengan komunikasi anak. Subdomain pertama di bidang komunikasi adalah pengembangan bahasa reseptif. Anak-anak mengembangkan bahasa reseptif saat mereka mendengarkan orang dewasa dan teman sebaya dan terlibat dalam kegiatan kelas yang meningkatkan pemahaman mereka tentang penggunaan bahasa. Tujuan pengembangan khusus pada subdomain ini meliputi membantu anak untuk mengembangkan kesanggupan anak untuk mendengarkan cerita, lagulagu, dan sejenisnya; membantu anak-anak mengidentifikasikan konsep-konsep melalui pemahaman dari kata-kata label; meningkatkan kemampuan anak untuk merspon perintah atau direksional; dan membantu anak-anak belajar untuk bereaksi terhadap komunikasi satu dengan yang lain. (Bryen \& Gallagher dalam Catron dan Allen: 1999).

Catron dan Allen

menambahkan perkembangan bahasa reseptif yang terbaik dapat dibina dengan memberikan banyak kesempatan pada anak-anak untuk berinteraksi dengan orang dewasa dan teman sebaya serta berpartisipasi dalam berbagai kegiatan 
seperti mendongeng dan bermain drama/bermainperan. Disamping itu kegiatan-kegiatan khusus dapat mengembangkan keterampilan bahasa pada bahasa reseptif.

Domain kedua di bidang komunikasi adalah perkembangan bahasa ekspresif. Sebagai anak-anak mengembangkan keterampilan bahasa ekspresif mereka, meningkatkan kemampuan untuk berkomunikasi dengan orang lain. Mengekspresikan kebutuhan dan keinginan mereka dan mempengaruhi di seluruh kata mereka. Tujuan perkembangan spesifik di subdomain ini meliputi membantu anak mengungkapkan kebutuhan, keinginan, dan perasaan secara lisan; mendorong anak-anak untuk berbicara dengan jelas sehingga mudah dipahami; mendorong perkembangan kecepatan berbahasa lisan; membantu anak memehami bahwa komunikasi mereka secara aktif dapat mempengaruhi lingkungan fisik dan sosial mereka. (Bryan \& Gallagher, dalam Catron dan Allen: 1999)

Pengembangan keterampilan bahasa ekspresif paling difasilitasi secara terbuka, lingkungan kelas responsif dimana anak-anak memiliki banyak kesempatan untuk berkomu-nikasi dengan orang dewasa dan teman sebaya.Subdomain ketiga dalam bidang komunikasi meliputi proses komunikasi nonverbal. Komunikasi nonverbal adalah alat yang ampuh untuk mengekspresikan emo-si dan memahami perasaan lain. Anak-anak belajar untuk menjadi efektif jumlah komunikator ketika mereka dapat menyesuaikan pesan nonverbal dan verbal mereka. Tujuan pembangunan spesifik di subdomain ini meliputi membantu anakanak mengekspresikan perasaan dan emosi melalui ekspresi; membantu anak-anak mengekspresikan keinginan dan kebutuhan melalui tubuh/ gerakan tubuh; dorong anak-anak untuk membangun kontak mata ketika memulai untuk membangun kontak mata ketika memulai interaksi dengan orang lain; membantu anak-anak belajar untuk mengirim sinyal komunikatif nonverbal yang kongruen dengan pesan verbal.

Pengembangan keterampilan komunikasi nonverbal berlangsung ketika anak-anak memiliki berbagai kesempatan untuk berlatih interaksi dengan teman sebaya di kelas. Anak-anak muda yang mengembangkan teknik komunikasi nonverbal dan kemudian menerima, membantu dan mendukung umpan balik dari orang lain menjadi komunikator yang lebih efektif.

Hasil penelitian ini juga mengungkapkan bahwa anak usia 5 tahun sudah mulai dapat bercanda dengan katakata. Anak-anak mulai bercanda dengan mengelabui peneliti dengan pernyataan bahwa dirinya sudah kelas $1 \mathrm{SD}$, padahal dia masih TK. Dia menyatakan kebohongannya itu dengan tertawa dengan maksud untuk bercanda, walaupun peneliti awalnya mengiyakan dan percaya, tapi di lain sisi teman-temannya ikut tertawa keras dan mengklarifikasi bahwa yang dimaksud anak tadi bukan seperti yang dikatakan, dan mengatakan bahwa dia masih duduk di bangku TK B.

Hasil penelitian ini senada dengan pendapat Otto (2010) yang menyatakan bahwa anak TK mempunyai selera humor dan mengindikasikan ada perkembangan pengetahuan semantiknya. Teka-teki dan bercandanya sering berdasarkan pada perbandingan semantik atau kata yang mempunyai makna yang jamak. Umumnya guyonan yang dimunculkan polanya dapat diprediksi dan dapat dengan mudah diciptakan, tapi sesekali guyonannya tidak relevan dan tidak lucu bagi orang dewasa, tapi anak-anak tetap suka, tertawa dan menikmatinya.

Peneliti-peneliti seperti yang dirangkum oleh Otto (2010) sepakat bahwa guyonan yang diciptakan anak usia 5 tahun keatas mencerminkan kesadarannya terhadap pola bahasa dan kemampuannya dalam memanipulasi kata untuk menciptakan ide humor. Humor yang diciptakan anak juga 
mengindikasikan anak sudah menyadari keganjilan/ ketidakpantasan, situasi tersebut dikatakan lucu karena ketidaksesuaian anatar apa yang seharusnya terjadi dan apa yang telah terjadi sekarang. Otto (2010) juga menambahkan pendapat peneliti lain bahwa melalui humor yang dicipta-kan anak, dapat meningkatkan peng-kayaan kosa kata anak. Terkait dengan perkembangan semantik anak usia 5 tahun, Dardjowidojo (2012) menyatakan dalam penguasaan makna kata anak menghadapi banyak kendala karena kata memiliki derajat kesukaran yang berbeda-beda. Pada umumnya, kata-kata konkrit lebih mudah daripada yang abstrak dan karenanya lebih mudah serta lebih cepat diperoleh.

\section{KESIMPULAN}

Kemampuan penggunaan kata kerja anak usia 5 tahun sudah mengalami perkembangan yang pesat. Penelitian ini mengungkapkan bahwa kata yang dihasilkan oleh anak usia dini sangat banyak. Kata kerja yang diucapkan sudah dapat diketahui dan dipahami oleh lawan bicaranya. Data yang muncul, pada tahap ini anak dalam menggunakan kata kerja masih menggunakan kata dasar. Pengucapan anak dalam menggunakan kalimat beberapa masih belum jelas. Penelitian ini mengungkapkan bahwa penggunaan kata kerja pada anak usia 5 tahun tidak diimbangi dengan penggunaan kalimat yang lengkap/ kompleks. Penelitian ini juga mengungkapkan bahwa anak usia 5 tahun sudah mulai dapat bercanda dengan kata-kata.

\section{SARAN}

Saran untuk para pengembang bahasa anak usia dini, dalam mengembangkan bahasa anak sebaiknya melihat perkembangan bahasa yang telah diperoleh anak, karena setiap anak memiliki tahap perkembangan yang unik dan berbeda dengan anak lainnya.

\section{DAFTAR PUSTAKA}

Beaty, Janice J. (2013). Observasi Perkembangan Anak Usia Di-ni. Jakarta: Kencana Prenada-media Group.

Brown, H. Douglas. (2007). Prinsip Pembelajaran dan Pengajaran Bahasa. Terjemahan Noor Cholis,dkk. Jakarta: Kedutaan Besar Amerika Serikat di Ja-karta.

Catron, Carol E. \& Allen, Jan. (1999). Early Childhood Curri-culum. A Creative Play Model. Second Edition. USA: Pren-tice-Hall.Inc

Dardjowidjojo, Soenjono. (2012). Psikolinguistik, Pengantar Pemahaman Bahasa Manusia. Jakarta: Yayasan Pustaka Obor

Dharmowijono, Widjajanti \& Su-parwa, I Nyoman. (2009). Psikolinguistik, Teori Kemam-puan Berbahasa dan Pemero-lehan Bahasa Anak. Denpasar: Udayana University Press

Gestwicki, Carol. (2007). Developmentally Appropriate Practice, Curriculum and Development in Early Education. Third Edition. Canada: Thomson Delmar Learning

Jalongo, Mary Renck. (2007). Early Childhood Language Arts. USA: Pearson Education, Inc

Kementrian Pendidikan Nasional. (2009). Permendiknas Nomor 58 Tahun 2009 tentang Stan-dar PAUD. Jakarta

Kementrian Pendidikan Nasional. (2009). Undang-Undang No-mor 20 Tahun 2003 tentang Sistem Pendidikan Nasional. Jakarta 
Kostelnik, Marjorie J., Soderman, Anne K., \& Whiren Alice P. (2007). Developmentally Ap-propriate Curriculum. Best Practices in Early Childhood Education. Fourth Edition. USA: Pearson Prentice Hall

Masnipal. (2013). Siap Menjadi Guru dan Pengelola PAUD Profesional (Pijakan Mahasis-wa, Guru \& Pengelola TK/RA/KB/TPA). Jakarta: PT Elex Me-dia Komputindo

Musbikin, Imam. (2010). Buku Pin-tar $P A U D$. Jogjakarta: Laksa-na

Otto, Beverly. (2010). Language Development in Early Child-hood. Third Edition. New Jer-sey: Pearson Education, Inc

Sujiono, Yuliani Nurani \& Sujiono Bambang. (2010). Bermain Kreatif Berbasis Kecerdasan Jamak. Jakarta: Indeks

Yamin, Martinis\&Sabri, Jamilah. 2010. Panduan Pendidikan A-nak Usia Dini. Jakarta:GP Press 